\begin{tabular}{c} 
Volume and Issues Obtainable at Center for Sustainability Research and Consultancy \\
Journal of Business and Social Review in Emerging Economies \\
ISSN: 2519-089X (E): 2519-0326 \\
Volume 5: No. 2, December 2019 \\
CSRᄃ \\
Journal homepage: www.publishing.globalcsrc.org/jbsee \\
\hline
\end{tabular}

\title{
Uncovering the Systematic Genocide Against the Hausa-Fulani and Muslims Groups in Nigeria
}

\author{
${ }^{1}$ Isah Shehu Mohammed, ${ }^{2}$ Muhammad Fuad bn Othman, ${ }^{3}$ Nazariah binti Osman \\ ${ }^{1}$ General Studies Department, Federal Polytechnic, Bauchi, Bauchi State - Nigeria, zababa72@yahoo.com \\ ${ }^{2}$ School of International Studies, Universiti Utara, Malaysia, mfuad@uum.edu.my \\ ${ }^{3}$ School of International Studies, Universiti Utara, Malaysia, nazariah@uum.edu.my
}

\begin{tabular}{l} 
ARTICLE DETAILS \\
\hline History \\
Revised format: November 2019 \\
Available Online:December 2019
\end{tabular}

Keywords

Hausa-Fulani, Muslims, Nigeria, Genocide, Endangered Groups

JEL Classification:

N10,N17

\section{ABSTRACT}

Objective: The objective of this study is to uncover the systematic but neglected genocide against the majority Hausa-Fulani and Muslims groups of Nigeria and alert all the stakeholders.

Methodolgy: The used qualitative research (non-statistical) design to investigate and uncover the genocide. Secondary sources were used for collection of the data from books, journals articles, press releases, rejoinders, public records and historical texts and materials; the data was also analysed using the qualitative and historical methods of data analysis.

Results: The results show that over the years, there is factual systematic genocide against the Hausa-Fulani majority and the Muslims groups in Nigeria by the non-Muslims using various means and strategies - peaceful and violent, historical narratives, the media, public offices and positions; the various Nigerian state authorities have not been taking enough measures to avoid or stop the genocide. The genocidaires are and their actions are known to the Nigerian state authorities and in most instances move and operate with impunity.

Implication: The study found evident systematic genocide against the Hausa-Fulani and Muslims in Nigeria. Immediate and remote legal, political and socio-economic measures must be taken by the Nigerian state authorities as the situation is further degenerating, and threatens humanity, Nigeria's unity and sustenance.

(C) 2019 The authors, under a Creative Commons AttributionNonCommercial 4.0

Corresponding author's email address: zababa72@yahoo.com

Recommended citation: Mohammed, I. S., Othman, M. F. B. and Osman, N. B. (2019). Uncovering the Systematic Genocide Against the Hausa-Fulani and Muslims Groups in Nigeria. Journal of Business and Social Review in Emerging Economies, 5 (2), 247-262

DOI: $10.26710 /$ jbsee.v5i2.826

\section{Introduction}

Humankinds, a naturally violent specie have throughout history, been characterized by violence, especially killing one another, as human psychology is created with the urge to humiliate, torment, wound and kill others (Glover, 1999:33). Thus, humans have come to terms with living in a world that requires, survives on and rewards aggression and violence (Alvarez, 2010:104). Genocide has also been part of the early history of humankinds on earth and with time, becomes more systematic, extensive and thorough (Jones, 2011:3-4; Weitz, 2003:8; Moses, 2008:8; Lattimer, 2007: xi). As the world becomes more sophisticated with technology, globalization, and 
development, so also do the human wickedness and cruelty increase. In less than a century (1900-1987), about 170 million people were killed in genocides and mass murder around the world (Rummel, 1994). Not only through physical violence, genocide is also perpetrated and executed through diseases, malnutrition, starvation, forced sterilization, dislocation, displacement and rape (Alvarez, 2010:7 \& 12). The MHF groups of Nigeria are currently faced with such genocide that is related to those of other Muslims in Chechnya, Rohingya, Uighurs/Turkic Chinese minority Muslim, Bosnia (Bosnians and Armenians), and Cambodia and Vietnam (against the Monks religious group) where between 90 and 95\% of them were killed between 1975 and 1979 (Hinton, 2005:23). The United Nations (UN) in 2017 confirmed that genocide is being executed against the Rohingyan Muslims in Myanmar.

Previous studies have mainly focused on ethno-religious conflicts on the northern Nigeria; the alleged decades long genocide proclivity in northern Nigeria against the Igbos, Christians and other non-Muslims; use of exclusionary ideology and imposition of the Sharia Islamic laws "through enforced assimilation or extermination of Christians and other non-Muslims who do not assimilate or adopt the Muslim ideology" Okoye (2013: xv). From available literature, no extensive study has been conducted to explore the systematic genocide against MHF of Nigeria. Therefore, this study uncovers the systematic, covert and overt genocide being executed against the MHF amidst deliberate bad publicity, orchestration of conflicts and violence, hiding the Christian and other non-Muslims atrocities, and a of game of blame the victims (Muslims) by the Christians and other non-Muslims, specifically from the north and other parts of Nigeria. While the Igbos have been falsely using the alleged genocide against them as a means of garnering local, international and ethno-religious sympathy and appeal (David, 2018:27).

The study is very significant and timely as the world is fast dipping into more and more, but systematic cases of genocide, and as the former United Nations Secretary - General late Kofi Annan maintained, "there can be no more important issue, and no more binding obligation, than the prevention of genocide" (Kofi Annan, 2004). Furthermore, Nigeria's unity and stability are further threatened by the genocide.

\section{Statement of the Problem and Justifications for the Study}

Genocide has been a major threat to not only individual states and societies, but also to the contemporary international order and has been on the increase with escalations in the destruction of indigenous peoples' ways of life and deprivation of peoples' human rights (Gallagher, 2013:18-9; Totten \& Parsons, 2009:1; Weitz, 2003:8; Gellately \& Kiernan, 2003:3). While ethno-religious hostility is the worst form of violence in human history that completely eliminates opponents/enemies (Midlarsky 2005:75), there is a systematic genocide against the MHF groups of Nigeria. The groups are completely gripped in fear, uncertainty and pessimism, especially from the North where hate, gruesome killings, guerilla war, and elimination have been declared and normalized against them; thousands of children and women are being un-naturally turned orphans and widows; properties/investments worth billions of Naira being destroyed,; they no longer travel around Nigeria freely as they are murdered/hacked to death with impunity; they live in a state of hate, negative stereo-typing, and blame the victim game (Hassan, 2015:40). Properties are being lost, and apart from the use of local weapons, there are increased use of sophisticated weapons - artillery guns, bazookas, and the deployment and use of ex-soldiers as fighters by the ethno-religious groups against the MHF (Arowosegbe, 2016:7-8); between 1999 and 2015, over 5,500 Hausa-Fulanis were killed by the Odua Peoples' Congress (OPC) and local vigilantes members in Oyo and Saki; within the same time, and about 12,000 Fulani pastoralists were killed by the OPC members in "Ajegunle, Eruwa, Gaa Kondo, Igbo-Ora, Ijebu Ode, Imeko, Ikenne, Iseyin, Mushin, Owode Egba, Oyo town, Saki, Sagamu, Sango-Ota, Waasinmi and Yewa" in South-Western Nigeria (Arowosegbe, 2016:15).

There is a conspiracy of psychological genocide among the non-Muslims and the Nigerian Christian dominated Media, especially the Southern based; some elements in the conventional security agencies are being used to destroy/distort evidences and exhibits, frustrate cases/thwart investigations/complaints by the victims; nothing is being done to the perpetrators of the genocide as most of the times, governments deliberately or otherwise aid and abet genocide (Totten \& Parsons, 2009:3).

This target groups which constitutes over $29 \%$ and $50 \%$ of Nigeria's ethno-religious groups composition are being un-naturally and violently killed, scapegoated, despised, resented, stereo-typed, laced and mocked at in an increasing and escalating rate (Mohammed, 2018:118, 119, 132). 


\section{Literature Review}

The term genocide is derived from two Greek and Latin languages words - 'Genos' meaning 'race' or 'tribe', and 'cide' meaning 'killing' respectively and both were coined by Raphael Lemkin (Card \& Marsoobian, 2007:13, 1516; Mayersen, 2016:3, 5-6). Genocide is difficult and controversial to define because of relativities, variables and dynamism involved in it; it changes as policies/means of destruction change in order to fit dynamic/evolving environments and conditions (Alvarez, 2010:7-9; Gallagher, 2013; Alvarez, 2010; Totten \& Parsons, 2009:3-4; Jones, 2011:13; Shaw, 2015:4). Ervin Staub (as cited in Newman and Erber, 2002:13) has observed and asked why a government or group turns against another and maintained that it has to do with difficult life conditions, harsh economic situations, political conflicts, violence and war, decline in power/prestige and social disorganization.

For that, McGarry \& O'leary (1993:6-7) see genocide as systematic mass killing and or calculated destruction of a group, and the conditions essential for its survival. This destruction can be through social, economic, biological. Genocide is seen as the worst form of crime against humanity being "the ultimate, supreme crime, and the crime of all crimes" (Alvarez, 2010:1). For Gallagher (2013:1), genocide is simply "the destruction of a group", adding that prevention of genocide is apart from the 'humanity perspective', necessary when national interests are threatened. The UN Convention (Article II) defines genocide as:

Any of the following acts committed with the intent to destroy, in whole or in part, a national, ethnical, racial or religious group, as such: (a) killing members of the group; (b) causing serious bodily or mental harm to members of the group; (c) deliberately inflicting on the group conditions of life calculated to bring about its physical destruction in whole or in part; (d) imposing measures intended to prevent births within the group; (e) forcibly transferring children of the group to another group.

Similarly, Article III provides punishable acts as: "genocide; conspiracy to commit genocide; direct and public incitement to commit genocide; attempt to commit genocide; complicity in genocide".

Jones (2011:569-571) identifies warning signs/indicators of impending genocide as: past history of genocide and inter-communal conflicts; mobilization along lines of communal cleavages; hate propaganda; unjust discriminatory legislation and related measures; severe systematic state repression. Similarly, perpetrators of genocide come from all parts and ranks of a society - professionals, armed forces, political and business classes, and ordinary citizens (Alvarez, 2010:103). Genocide is therefore, a collaborative enterprise and there are several causes/reasons why individuals participate/engage in genocide as "individual/personal and group's history and life experiences, temperament and character, belief system, career and job, and family and community members" (Alvarez, 2010:105). In the same vein, Campbell (2001:11) laments that genocide is a trans-sovereign problem that threatens the entire world and has overpowered the capability of states and organisations to contain it and punish the perpetrators. Genocide has two phases: the destruction of the national pattern of the target group; and the imposition of the national pattern of the genocidaire (Lemkin, 2005:79).

Genocide has common ideological elements as: the notions of past victimization - belief of and historical suffering; dehumanization - viewing and treating self as more human and superior, and others as different, inferior or less human; scapegoating - the transfer of blame, woos and misdeeds unto others, rather than self in order to justify casting out killing the other(s); absolutist worldview - strong belief in un-compromise and non-accommodation of others as characterized by fundamentalist of ethnic nationalism and religious faith; and Utopianism - the ideology/attempt to purify, create, recreate a perfect/ideal society or community based on politics, ethnicity, religion, sectionalism (Alvarez, 2010:62-73; Midlarsky, 2005:74; Dutton, 2007:153).

Foundational to that, Mann (2005) has identified 9 types/categories of genocide perpetrators as: the ideological perpetrators - the social elites who believe in, sell, promote and justify the goals; bigoted perpetrators - the unimaginative and ordinary elements who join in the circumstances and become motivated to kill/harm others; violent perpetrators - individuals who like and enjoy violence and are excited to execute their violent craves; careerist perpetrators - those who participate in genocide to explore the chances and advance their careers/opportunities for jobs, power; disciplined perpetrators - the military, police, among others who work with and are confined to state institutions with loyalty/order/command-obey structures irrespective of the meaning or implications of such orders /commands; comradely perpetrators - those related to disciplined perpetrators, who participate in genocide on comradeship and spirit de corps basis with their sister institutions in solidarity; 
bureaucratic perpetrators (desk-murderers) - who through the state machinery and institutions ignore the sufferings, killings, close eyes on acts of the other perpetrators and authoritatively disregard the implications of such actions; materialists (profiteer) perpetrators - those who are stimulated to partake by material interests - greed, booty, political/economic/religious/traditional powers; fearful perpetrators - those who are forced by situations/circumstances to participate not because they believe in or like doing so, but for fear of consequences for refusal to participate in the genocide.

In the same vein, Okoya (2013:52-101), identifies causes of genocide as:

demographic factors, resource scarcity, and greed; threat and vulnerability; fear; in-group and out-group identity; narcissism; groupthink, hate processes and dehumanization of 'other'; manipulation and loyalty to authority; the human agency and collective evil; the nation-state; imperialism, colonialism, and modernity; ideological influences; power politics and genocide denial; humiliation; and race, racism, and crime.

Similarly, Sternberg (2003) maintains that hate is the main cause for many genocidal killings around the world and can also be carried out through diseases, malnutrition, starvation, forced sterilization, dislocation, displacement and rape (Alvarez, 2010:7 \& 12). Hence, it involves both direct and indirect violence. Milgram (1960: xi) observes that even individuals who do not believe/like violence against humanity can be easily involved in killing others when authorities or influential others direct/order them to do so. However, for Smith (2007:109), it is self-deception that stimulates and misleads individuals to human slaughter, especially for aching consciences, but despite partaking in such inhuman actions, individuals delude themselves by still believing they are 'compassionate, moral and pious'. This vivid description can be related to Nigerians who despite killing and leashing terror on others, still go to worship centres claiming to be godly and following the virtues of their religions.

With respect to humankinds and their inherent natural character, Glover (1999:33) observes that "deep in human psychology, there are urges to humiliate, torment, wound and kill people", and this affirms Sigmund Freud (cited in Smith, 2007:61) who also maintains that "men are not gentle, friendly creatures wishing for love, who simply defend themselves if they are attacked, but that a powerful measure of desire for aggression has to be reckoned as part of their instinctual endowment". These reveal not only true character of humans, but also their fervent desire to leash wickedness/cruelty on others.

The Duplex theory of hate identifies three triangular components of hate as: the negations of intimacy, commitment, and passion (Sternberg, 2003). Where and whenever these three occur, what results is not only violence, but also genocide against any target groups. Violence itself is caused by shame, ridicule, humiliation and disrespect (Gilligan, 1996:110). For that, where genocide occurs or is likely to, its tendencies are increased if the target group is seen as or appears to be related, sympathetic or supportive to the opposition/opponent/enemy (Alvarez, 2010:37).

For Nigeria and Nigerians, they are afflicted by what Putnam (2007:144-149) describes as the 'Constrict theory' which emphasizes that not only do heterogeneous settings increase mistrust among members, but also within the groups and their members due to contact and or vulnerability to the larger and diverse settings. This is tied to human interest in power and materialism and the fact that "in any struggle for power and its spoils, there is a usually thin line between one's moral position and one's concrete material interests" (Othman, 1984).

\section{Methodology}

This study used qualitative method in collection and the analysis of data. The study also used historical documentation and design method to collect the data from secondary sources. The historical design and documentation method enables a researcher to study and or search for facts from historically integrated and substantiated records. The study the background and heterogeneity of the Nigerian state, ethno-religious rivalries and conflicts which altogether boiled down to the genocide with theoretical framework built on Gain Strain theory. The study also adopted the United Nations standard provisions and Articles on genocide, which defines and specifies the various acts that constitute genocide. The study also analysed memoirs, press releases, and rejoinders among others by the prominent Nigerian religious bodies - Christian Association of Nigeria (CAN), Jama'atul Nasril Islam (JNI), Nigeria Supreme Council of Islamic Affairs (NSCIA), and National Christian Elders Forum (NCEF) among others. 
Other extensive and intensive literatures on genocide were also used for both quality and robustness of the data and analysis of the study. Available literatures and studies are on ethno-religious conflicts and alleged genocidal tendency against the Igbos of South-East Nigeria with non on the genocide against the MHF (Achebe, 2012:228; Young \& Isbell, 2000:33; Okoye, 2013; Okoye, 2014).

\section{Background and History of the Hausa-Fulani, Muslims (HFM) and Islam in Nigeria}

Nigeria is the result of the British colonial amalgamation of the two major areas of Niger River - North and South. The two were distinct in terms of geography, culture, religion, socio-political and economic settings, but were joined to form united Nigeria on 1 January 1914. Consequent to this, hundreds of ethno-religious and geo-political set ups were welded together into one country. Nwabueze $(1993: 21)$ notes that the heterogeneity of Nigeria is such that there are over 300 groups with fundamental differences in attitude, outlook, character and ways of life, and much more different than the English from Germans or French from the Italians. These differences and complexities explain why Bourne (2015:ix) observes that "anyone who claims to understand Nigeria is either deluded, or a liar".

For centuries before advent of colonialism, Muslims from Central Sudan (later Northern Nigeria) - with Kanuri, Hausa and Fulani tribes characterized by Islamic scholarship and culture had been well established in trans-Sahara trade (goods and slaves), arts and craftsmanship with presence and prominence in Timbuktu, Tripoli, Al-Quahira (Cairo) among others (Levan \& Utaka, 2018:20).

Similarly, there were also, before the 1804 Danfodio Jihad and later colonialism (from 1861), established Hausa states since the thirteenth Century and had by then became popular and in much control of the areas around the Central Sudan (Northern Nigeria), including the other multi-ethnic minorities and polities (Falola \& Heaton, 2008). Hausa then was the main language spoken in both official matters and lingua franca for the region. For centuries before, and during colonialism, those Hausa states remained strategic in both commercial, socio-cultural and scholarship linkages with the Maghreb, North Africa up to the Senegal Valley and the Far East of the Arabian Peninsula (Mohammed, 2018: 18-20; Farrington, 1963).

The Kanem-Borno rulers were the first to accept and convert to Islam between the tenth and eleventh Century. The Hausa Habe rulers also accepted Islam from around the fourteenth Century upward as interactions became increasingly manifest and influential between the Borno Empire, Hausa states and their rulers, and the Maghreb, North Africa, Middle East. The trade in the areas went simultaneously with the propagation of Islam, its values and influence, acculturisation and cross-culturisation with the North African and the Arabs. Thus Islamic scholars have gained and exercised much influence on the rulership in both the early Islamised Borno and the Hausa states that followed. Borno itself was an Islamic Caliphate, rather than Empire for its ruler (the Mai) had received a "Caliph" title from the Ottoman Empire around C1500 (Last in Levan \& Utaka, 2018:20). In addition to highly developed Islamic political system and Islamic scholarship (with specialization in the Holy Qur'an and Islamic calligraphy), Borno was the commercial centre/route and link for trans- Sahara trade just as Katsina and Kano also later became centres (Mohammed, 2018:23; Last in Levan \& Utaka, 2018:20-2; McCormick, 2010:438; Falola \& Heaton, 2008:33). These states together with Borno then formed both centres and a network for trade in the Central Sudan that linked the area up to Middle East. These explain the significant impacts and influence of Islam on the people, geography, history, life, customs and traditions, statesmanship, political-culture, economy and sociology of the later Northern Nigeria, comprising of Borno and other highly politically developed independent Hausa states of Kano, Zaria, Katsina, Daura, Gobir, Zamfara (Levan \& Utaka, 2018:21). However among all the states identified, Borno has been the one with the oldest history of political evolution and development alongside Islamic scholarship. Last in Levan and Utaka (2018:19) recalls and summarises that for over 2000 years, Northern Nigeria has been a centre on the outer fringes of the Middle-East with various routes and linkages with people through the Sahara desert to Egypt, Lake Chad, Phoenician Carthage and the Roman Empire. Additionally, by the 11 Century, Arabic has become the formal language used for business, scholarship and communication with Islam as the dominant and official religion in Kanem-Borno playing central role in politics, economy and scholarship.

On the other hand, different versions of stories on the origin and history of the Fulani and or their migration have been advanced. The most popular is that which posits that the Fulanis trace their origin from North Africa (Kalu, 2008:34); they are a product of Middle Easterns from the family of Abraham who through migration in search of pasture, moved and intermarried with the African Negroes, Egyptians, Hindus and Berbers, North Africa and the Sudan (Junaidu, 1957; Last, 1967; Johnston 1967). However, in the recent, historians and historical developments 
have provided another version that the Fulanis are originally the people of Africa, and did not migrate from anywhere. The population of Fulanis in Nigeria is a subject of controversy for they are dispersed and hardly become largely concentrated in one large area, but in small settlements and migrating from one vegetative area to another in search of good pasture, however, there are also substantial and increasing number of those who are adapting sedentary life and farming/cattle rearing (Mohammed \& Aisha, 2018:10-13). With that, Okello, Majekodunmi, Malala, Welburn and Smith (2014) provide that their population is over 12 million. Similarly, the largest number of the Fulanis are Muslims. There are, however Christians and traditional religionist among them (Mohammed \& Aisha, 2018:10-13; Johnston, 1967; Last, 1967).

Shiek Usman bn Fodio (1754-1817) was the most popular Jihadist and Islamic scholar/preacher in the history of the Central Sudan, West Africa and Africa South of Sahara. He was from a renowned Toronkawa Fulani clan and Muslim who were vastly learned in Islamic scholarship with over 30 eminent scholars among his kinsmen (Last in Levan \& Utaka, 2018:21). Usman bn fodio, whose Jihad in Hausaland commenced in 1804 established the most significant and historic Islamic Caliphate in the Central Sudan serially ranked after the Khulafaur-Rasheedun, the Banu Umayyad Dynasty, Abbasid Caliphate, and the Ottoman Empire respectively (Mohammed \& Aisha, 2018:12). The 1804 Jihad revived and further strengthened the significance and influence of Islam on the Central Sudan, which till date continues to impact on political economy, geography, ethno-religious, and socio-societal set up of not only the Northern part of and Nigeria, but around the Lake Chad, parts of the Sahel (Niger and Mali) and Central Africa (Cameroon and the Central African Republic, CAR). According to Okello et al. (2014:2) and Nwabara (1963:231-242), the Fulanis, who together with the Hausas, are at the central of controversy in Nigerian affairs and multi-dimensioned controversy, have a long and prominent association with politics, Islamic scholarship and wealth/mercantilism. Thus after the commencement of the Jihad in 1804 and the Eastern and Western capitals at Sokoto and Gwandu, Mohammed and Aisha (2018:12) note that the influence of the Fulani Islamic scholarship strengthened Islam in many parts of present Nigeria, including the southern part, as well as neighbouring states on the West and Central Africa.

The Europeans first came to what later in 1914 became Northern Nigeria in the middle of the sixteenth Century for mercantile and Christian religious missions (Last in Levan \& Utaka, 2018:19). Forceful conquest of the areas began with the occupation of Lagos in 1861. By 1899, the British colonialists had established their rule and dominance in the Northern part of the Nigeria and on 1 January 1900, the British hoisted the Union Jack (British flag) at Lokoja, geographically located at the centre of Nigeria (Fafunwa, 1991:101). The Sokoto Caliphate which had reigned from 1804 with several Muslim Emirates under it was defeated at the Giginya Battle outside the Sokoto fortified walls on 15 March 1903. The British thereafter established indirect rule, but preserved both the Islamic religion and the Sharia system (except for the criminal aspect dealing with Hudud/Quisas). The Colonialists actually understood the advanced Northern Islamic/Caliphal system in relation to their earlier experiences in Egypt and India. It was because of the high level of religious, political and socio-cultural settings and organization of the Emirates under the Sokoto Caliphate that the colonialists not only preserved the rule, but also trusted and worked more or less harmoniously with the Northern MHF during the Colonial/indirect rule period that lasted until independence. The North was also fortunate to be the geographically largest, most populous, and richest in terms of solid minerals compared to the southern (Eastern and Western) regions of the Nigeria. The latter, unlike the former, are smaller in terms of both geography, population and less endowed with material resources, apart from oil (Mohammed, 2018:95-97; Mohammed \& Aisha, 2018:16).

Essentially, while Islamic religion reached Northern Nigeria over a millennia ago from the Middle East through the North Africa/Maghreb countries, Christianity was brought in by the colonialist/missionaries. Although history has shown the presence of the Portuguese in the areas of present Nigeria from around 1471, Christianity as a religion was brought in and spread by the Missionaries at about the same time with colonial conquest and occupation of the areas around river Niger (Shehu \& Buba, 2016:213). Hence, Nigeria has a predominance of Islam and Christianity having reached the area as a result of trans-Sahara and trans-Atlantic contacts, trades, and evangelism. The two religions form the basis of substantial character of the Nigerian state and its main regions (North and South), which partly explains disharmonies in Nigeria. Noting the religious/regional disharmonies in Nigeria, Huntington (as cited in Roskin, 2007:531) describes Nigeria as a 'cleft country' that is divided between Islam and Christianity and portraying 'inter-civilisational disunity'.

Related to that, about $80 \%$ of Nigerians belong to the two prominent religions (Mooney, Knox \& Schacht, 2002:187 \& 193). However, there exists a great and probably an un-ending controversy on the accurate percentage 
of Muslims and Christians in Nigeria with varying and controversial figures provided as: Muslims 50.5\%, Christians 48.2\% (Agbiboa, 2013:19) and Muslims 50\%, Christians 40\% (Trinscizki, 2016:54). Alternatively and in the absence of accurate figures, the percentage of Muslims and Christians can be assumed to be more or less nearly equal (Okoro, 2017:468). For the Northern region, although there are non-Muslim, especially among the minority tribes, about 75\% of its total population are Muslims (Babalola, 2019:51).

\subsection{Colonial Policy and Legacy}

Being a colonial state, Akindola and Ehinomen (2017) and (Unegbu, 2003) have maintained that Nigeria is not only the result of colonial making, but still carrying the burden of difficult historical legacies of colonialism. The HausaFulani are generally considered to have been preferred by the British colonialists in terms of granting the north indirect rule, preservation of their religion (Islam) and traditional system, and being the colonialists' lieutenants or rather, agents of the colonialists (Turaki, 1993, Kukah, 1993; Ajayi, 2009; Okoye, 2013; Ochonu, 2008; Yahaya, 2016). However, as maintained by Mohammed and Aisha (2018:8 \& 93), Kalu (2008:34) and Mohammed (2018:134), the preference for the MHF by the British had to do with their precolonial established and developed socio-political, economic and ethno-cultural advancements in comparison to the others from both the others. Just like in India, the British colonialists had (during the colonial conquest) found a people with such an organized and developed socio-political, economic and religious system and settings. Thus the legacy of Hausa-Fulani prominence in both colonial and post-colonial era.

\section{From Ethno-Religious/Regional Rivalry and Conflict to Systematic Genocide}

From the 1914 amalgamation, the 1939 division of three protectorates of North, East and West, to the enactment of the federal system of government in 1954 and the subsequent events, Nigeria has been engulfed in forms of rivalries (Shehu, Othman \& Osman, 2017; Elazar, 1987:77; Kalu, 2008:65, 68, 78). These have however, later reached their peak and resulted in violence, relative injustice, and to some extent disaffection from the Nigerian state. It is at that critical stage that systematic genocides evolved against the MHF who are made the scapegoats of Nigeria's failure to reach the Promised Land. Thus, Shehu et al. (2017) maintain that the rivalry is 'old and creeping' also identify some of the dimensions rivalries as ethno-religious, economic, regional, and political and elitists.

In addition, ethno-religious/regional conflicts have become a dominant feature of the Nigerian state, especially from the 1980s to date. Alubo (2006:9) provided that between May, 1999 and 2004 there have been more than 89 recorded cases of ethno-religious related conflicts that were all violent and fatal. More so, the largest number of such conflicts occurred in the Northern states of Kano, Benue, Katsina, Borno, Adamawa, Plateau, Nassarawa, Kaduna, Taraba and Kogi states. For the same conflicts, Aliyu and Shehu (2015:75-76) identify some of the major ones which have been recurring since their first occurrences as those of Southern Kaduna, Jos, Tafawa-Balewa, Bauchi (Yelwa), Kaduna, Taraba (Nigeria Supreme Council of Islamic Affairs, NSCIA, 2018:1). There have also been others related as those of Sagamu in Ogun State between the Yoruba and the Hausa-Fulani and reprisals (1999); bloody clash between Muslim and Christian over Sharia implementation in Kaduna (2000) and reprisals in Eastern Nigeria; numerous clashes between OPC militants and Hausa/Fulani in Ajegunle, Lagos State; reprisal attacks to Jos September 2001 killings in Eastern Nigeria; the Yelwan Shendam conflict with over 650 deaths; ethno-religious conflict between OPC and Muslim community over building the Ogun Shrine in a Muslim praying ground in Ipakodo, Lagos State (2005) among others (Halliru, 2012-216). Such conflicts and killings have not only continued since the early 1980s, and from 1999 respectively, but also escalated in the recent years due several factors identified below in this study.

On the other hand, with about 170 million people killed in genocides and mass murder around the world between the years 1900 and 1987 as Rummel (1994) laments, subsequent genocides have proved that the world is increasingly challenged by threats of and continuity of genocides against groups. The lives and fate of the MHF are put under the same threat. Those have large been due to their majority population in Nigeria, popularity in political power, and dominant role in national politics and being Muslims. In the recent, the groups have come under increasing oral and physical attacks, with ethno-religious motives of hatred, ethno-religious nationalism, which have increasingly become genocidal as manifested in various hate speeches, violent actions and reactions which have consistently been enveloped in incessant attacks on the lives and properties of the group in many parts of Nigeria. Such attacks have become a systematic genocide agenda in which the mass killings, carnages and hate have measured up to both national and international standards of genocide which have also been admitted by 
Nigerian Army (Mohammed \& Aisha, 2018:6, 104; Daily Trust, July 3, 2017, pp.1 \& 53, March 2 \& 3, 2018. pp.4 \& 6).

\section{The Systematic Genocide against the Hausa-Fulani and Muslims (HFM) Groups in Nigeria}

Genocide does not only mean or limited to instant destruction of a group through mass killings, but also through non-violent means and actions aimed at destroying the basis (economic, educational, psychological, socio-cultural, ethno-religious, geo-physical among others) of life of the group; and then annihilating it (Lemkin, 2005:46). According to Alvarez (2010:40), with exposure to the horrors of war, violence and then genocide, "people become desensitized to the realities of the violence; inhumanity becomes all too common and to all human. That which once seemed extreme and unimaginable becomes routine and almost normal". This explains why violence and other genocidal acts occur and escalate in Nigeria. The genocide execution against the MHF is both multi-dimensioned and systematic and qualifies for the UN standard definition and classification of genocidal acts. These include deliberate exclusions, killings, mental/psychological harm/manipulation and subjection to being (apologetic, inferior, guilt concise, shame, scapegoating). Between 1980 and 2019, there occurred hundreds of mass killings of the MHF in various parts of Nigeria with the highest number in Middle Belt/Central Nigeria; over 10 different fatal clashes between the Hausa-Fulani and Yorubas in Lagos from 1999 to date; the Tafawa Balewa crises (1991, 1995, 2001 and 2011) in which tens of thousands of all the MHF were forced out and taking refuge in other towns and cities while all their houses, the 45 daily and 3 Friday prayer mosques were destroyed, and from 2011 to date) not a single Muslims lives in Tafawa Balewa - a town originally established by the MHF over a century ago (Mohammed \& Aisha, 2018:17); the MHF in many parts of the Plateau, especially Riyom, Jos North and Barikin-Ladi have known no peace from 2001 to date with thousands dead, their families/communities broken and displaced, businesses crippled; in Yelwan Shendam, as a result of the 2005 ethno-religious crisis in which over 650 were killed; the MHF in many parts of Taraba state have been under siege, incessant and multi-faceted attacks by nonMuslims, as they with their properties and farm lands worth billions of Naira are being killed and destroyed/confiscated by the so called indigenous non-Muslims ethno-religionists; in 2017, there was the Mambilla genocide against the Fulanis who were attacked without any prior form of contention or disagreement and over 800 of them were killed, hundreds of their animals hacked to death, their settlements completely razed while the perpetrators celebrated with impunity (Saidu, Rasheed, Zakuan and Yusoff, 2019); and the serial attacks which follow, but remain unreported or given little publicity due to media conspiracy which is part of the grand genocide.; the enactment of Anti-Grazing/Night Grazing Laws in Benue, Taraba and Ekiti States which tactically deprived the Fulani (largely Muslims) the rights to free movement and property, and dispossessed them of their legitimate properties and means of livelihood; the multitude killings and carnages in other parts of the country - Sabo and IleIfe, Osun state, 2017).

There are deliberate orchestration of violence and provocation against this group to instill provocation and reprisal in order to execute the systematic genocide, and then blame the victim (Hassan, 2015:40), while the atrocities committed against the group are hidden. There is also collaborative conspiracy with the Media to close eye on the genocide on one hand, but overblow any attempt/move by the group to counter such and or assert their rights. There is also a brazen indecision by some Nigerian authorities to contain the atrocities against the group as characterized by bureaucratic perpetration of the genocide. These have altogether in addition to the genocide against the particular group, resulted in refuges problem, socio-economic dislocation and disorder, increased threat to national security and stability.

\subsection{Calumny, Manipulation of History and Historiography}

The genocide has been preceded by and now goes simultaneously with campaigns of calumny, manipulation and change of historiography of Northern Nigeria, especially the Middle Belt as the MHF image, character, historical records and materials, are being rejected, damaged and tattered in museums and before other Nigerians and before the world through both ethno-religious nationalism and writings (Suleiman, 2015; Okoye, 2014; Kukah, 1991; Okoye, 2013; Turaki, 1993; Ochonu, 2008).

With the ethno-nationalist historiography, some sections of Nigeria and Nigerians, especially the Middle Belt, and some ethno-religious nationalist are determined to change the course of history in order to re-define MHF in order to further give the bad name and image before the non-Muslims and the World (Suleiman, 2015: 112-115, 127, 183-184, 217; Mohammed \& Aisha, 2018: 90-96). This has reached an extent where visitors (non-Muslims) to the Museum in Jos reject (as written in the Guest book) 'Islamic symbolism' and resist archiving materials associated with MHF. A reactionary historiography has been schemed and being written by both amateur historians and ethno- 
religionists in order to not only change the course of history, but create new stories and narratives of the past slave raid and trade, the Jihad and re-define the past relations of the MHF, and the non-Muslims (Mohammed \& Aisha, 2018; Suleiman, 2012; Suleiman, 2015; Blench, 2011). The desperation to re-write this history has been lamented by Suleiman $(2015: 24,216)$ and Mohammed \& Aisha (2018:94-95) pointing out that even journalists, engineers and civil servants have become involved the reactionary historiography, and ethno-religious/nationalist re-writing of such history.

\subsection{Pilot Indigene/Settler Conflicts}

Nearly all endeavours of Nigerians with the 'others' (religions, regions, groups) are associated with and subjected to indigene/settler which has resulted in increased hatred, domination, instabilities and superiority/inferiority complex among Nigerians (Aliyu \& Shehu, 2015:74:75). Indigeneship has become a generator and trigger of violence in most parts of Nigeria as Fourchard (2015:54) maintains, and it has particularly been one of the pilots of the genocide against the HFM groups. Although not peculiar to the MHF alone, indigeneship has through the history to this genocide level, hit them more than any other group in Nigeria having been living for centuries in other lands in search of pasture, and engaged in trade and religious propagation.

Tied to the indigeneship is the deliberate social exclusion and denial to the MHF of even the basic rights entitled to all citizens of the Federal Republic of Nigeria in most instances such as establishment of worship centres, especially in the South Eastern part of Nigeria with predominantly Christian population, exclusion from public employment opportunities even in their indigenous states such as Plateau, Taraba and Benue; and exclusion from basic and social services; denial of indigeneship certificates, rights and non-recognition as bonafide citizens.

\subsection{Scapegoating against the Hausa-Fulani and Muslims (HFM) on the Dilemma and Problems of Nigeria}

Scapegoating, which Alvarez (2010:68) describes as the "practice of blaming individuals and groups for the misfortunes befalling a society or community", has been a major element that is being used in executing the genocide against the MHF. This is in line with Jones (2011:569) submission that "When the material base of peoples' lives is thrown into question, they are prone to seek scapegoats among minorities (or majorities); to heed to an extremist political message; and to be lured by opportunities to loot, pillage, and supervene".

Similarly, when a society, group or community finds itself consumed into its own woos, it is maintained by Douglas (1995:41), that due to ignorance of true causes of their suffering, such people look for explanations to why such and in the process, if true reasons are hidden or not found, explanations that would sound and look appealing to the people have to be given, which result in violence against scapegoats. Hence, the HFM who are more prominent and dominant among the ethno-religious groups are put to blame, being cast out and killed in order to arrive at an appealing and emotional cause of failures by the Nigerian state, and the other groups even where there are no correlations with that. The scapegoating has two main dimension - national and regional. The national dimension is between MHF, and the other Nigerian groups; while the regional has to do with the Northern Nigerian minority groups. In either, the MHF are the orchestrated scapegoats for failures. Naturally, governments, groups, leaders and individuals avoid taking responsibility of failures, but rather, put the blame on others (Alvarez, 2010:69; Douglas, 1995:41; Joseph \& Randall, 2009). Many, particularly the Southerners, including their elites, hold the belief that the North (MHF) is the power 'dominating region' (Lenshie \& Akipu, 2014; Kukah \& Falola, 1996:49-50; Ajayi, 2009; Okoye, 20013; Ajayi, 2009; Kukah \& Falola, 1996; Osaghae, 1998; Mohammed, 2018; Paden, 1986; Clark, 1991). Therefore, what Alvarez (2010:68-70) identifies as the sins and misdeeds by Nigeria and Nigerians through the years 1914 to date, are shouldered on the MHF groups in order to cast out, kill and eliminate them. The group now viewed and treated as different and inferior with despise, stereotype and prejudice. This has also resulted against the group in what Erik Erikson (as cited in Stevens 2004:43) and Alvarez (2010:66) describe as pseudospeciation, i.e., the mentality of considering oneself or group as the superior or rightly/really humans, and that other humans, especially those you do not like are inferior, or less human.

\subsection{Brazen Lies, Fallacies and Conspiracies against Islam and the Hausa-Fulani and Muslims (HFM) Groups}

Out of ignorance, misconception and in the attempts to deliberately discredit the target group and Islam, numerous submissions full of conspiracies, fallacies and concocted lies are forwarded. For instance, Eme (2012:191-203), Ikegbu (2010:119-126) portray the clamour and implementation of Sharia for the Muslims as an agenda for imposition of Islamic legal system and to Islamise Nigeria (Othman, Osman and Mohammed 2019:91), and link 
Boko Haram to the Muslims/Northern Nigeria generally. Others mischievously trace the Dan Fodio Jihad attempts and maintain that the MHF see nothing good in anything/everyone except themselves as Lenshie \& Akipu (2014) portray the MHF as those who think "nothing was good for the north which is not Muslim dominated".

Kukah and Falola (1996:2) present one of the misleading narratives stating that whereas both Islam and Christianity aim at winning more converts, unlike Christianity and Christians in Nigeria, Islam and Nigerian Muslims (the powerful Islamic elites) are a political force, ambitious and desirous to make Nigeria an Islamic state. Similarly, Falola (1999: 169-170) also alleges that Muslims tried to make Abuja an 'Islamic city' with construction of mosques in strategic locations, and mounted some designs and structures according to Islamic architectural values, in addition to hanging on to power in order to further promote Islam in Nigeria. In the same vein Kukah and Falola (1996:195) tactically allege that violence is instituted in Islam and its propagation, and Muslims have adopted it unlike the Christians and Christianity which teaches love and persuasion.

Further to that, Okoye (3013:142) alleges that Muslims do 'exclusionary ideological stance' and further asks the position of Christianity on such; and then answers herself that they do not, as the Muslims exclude Christians because of Sharia. One then wonders whether the Christians should be included in the implementation of Sharia or be allowed to practice their own (Chriistian) faith just as the Muslims want Sharia for themselves only. To her, it is the Muslim extremists who exclude Christians because of Sharia, but one then questions if "excluding the Christians from Sharia issues and implementation is justice or injustice to them?" This is because they neither belong to Islam nor like the Sharia.

\subsection{The Use and Manipulation of the Social Media}

The social media has throughout the world become a means used to spread propaganda, rumours, gossips, graffiti, and hate political and religious speeches among others (Jones, 2011:570). For Nigeria, numerous texts, video and audio clips, photographs from prominent religious clerics and ethno-regional leaders and elites are viral, calling on and inciting their congregations and kinsmen to violence against the Fulanis, the HFM just as hate speeches have become normalized among Nigerians (Mohammed \& Aisha 2018:102; Osaghae 2017:50; Ezeibe \& Ikeanyibe 2017; Mohammed \& Aisha, 2018:104; Daily Trust, 8 January 2018, pp. 1 \& 8; Gambari, Agwai, Ibrahim, Jega, Kwaja, Fesse, Oyebode \& Yau in Daily Trust 9 January 2018, pp. 10-11).

\subsection{Given the Groups Bad Name, Publicity, and Blame the Victim Agenda}

MHF, who are the actual victims of the genocide are tagged as "the perpetrators' who 'are intent to cleanse the north of Christians, the Igbos and other non-Muslims through the exclusionary ideology of imposition of Sharia law to force assimilation or extermination" as refutably asserted by Okoye (2014: xvi-xvii). As such, they have become not only a subject of ridicule, but also pushed into the game of 'blame the victims' by the Christians and others who hide under the banner in executing the genocide, and thereupon blame the victims, especially in the North (Hassan, 2015:40). The blame is tactically put on the victims using the numerous, but biased media outfits and influence, some state apparatus, propaganda, re-orchestration of such violence and conflicts, and killing and maiming them (Mohammed \& Aisha, 2018). On a particular note, it has been observed contrary to Okoye's alleged submissions that the Igbos in particular, have been falsely using the alleged genocide against them as a propaganda aimed at garnering local, international and ethno-religious sympathy and appeal for political, material and other motives (David, 2018:27).

\section{The Perpetrators in Action}

There are several perpetrators of this systematic genocide - some disgruntled members of the public service (retired and serving), the private individuals as well as from the general public. While some of these perpetrators work for the public and are paid from the public treasury, they are involved in as bureaucratic and working together with the all other perpetrators as identified by Mann (2005). The case of Mambilla genocide against the over 800 Fulanis has proved to the world that some Nigerian state authorities are involved in as bureaucratic (desk-murderers), the ideological, bigoted, violent (the killers/destroyers), careerist, disciplined, comradely, materialists (profiteer), and fearful perpetrators. The identified perpetrators include politicians, security agencies who leak official intelligence, those who physically kill/destroy, beneficiaries in material and career forms, and those who involuntarily participate for fear of being attacked if they refuse to participate in the genocide. Additionally, other common citizens can be and are also involved in genocide as Milgram (1960:6) observes that "ordinary people, simply doing their jobs, without any particular hostility on their part, can become agents in a terrible destructive process". Many 
of the Nigerian state authorities are not living up to their leadership responsibilities which entails responses to changes (Chow, Salleh \& Ismail, 2017).

A clear case involving collaboration of these perpetrators is that of Taraba state government in a letter dated 8 September 2017, the then Taraba State Attorney General and Commissioner of Justice, Mr. Yusufu N. Akirikwen directed the state Police Commissioner to within 24 hours unconditionally release all the suspects earlier arrested (in connection with the Mambilla genocide) by the Nigerian Army and handed over to the State Police Command. All the suspects were instantly released. This was despite the fact that the survivors of the Mambillla genocide identified and named most of the suspects as those who killed and destroyed their properties and the Nigerian Army had instantly and formally alerted the Nigerian Federal Government of the act as genocide that was worse than the Boko Haram atrocities.

In a related incidence, a member of the Nigerian Parliament had before the National Assembly informed the world that some influential people, including politicians were involved in the perpetration of such acts against the Plateau people, including purchase and importation of arms into Nigeria from Israel, establishment of training camps which are used to train ethno-religious militias in certain locations and states across Nigeria, and financing the entire actions. The parliamentarian offered to make himself available to Nigerian authorities and to prove (with documents), but nothing was done by the authorities; in Benue state, the state government was found to have been involved in establishing illegal training camps, training and sponsoring ethno-religious militias who kill and torment people under banner of Fulani-herdsmen-farmers conflict. In all these and others, nothing was done by the Federal government; not a single influential perpetrator was arrested, prosecuted and punished accordingly. Rather than take necessary actions, what happened in some states is ignoring such facts and then continuous persecution, attacks, exclusion and displacement of the MHF, especially in Taraba and Benue states, where the fate of the Muslims is left into the hands of the Christian dominated/biased and overtly anti- MHF states governments, and the CAN which is the major covert influencer of most public policies making in those states. Despite the secular provisions in the Nigerian Constitution, CAN is covertly influencing nearly all decisions, appointments, resource allocations among others in these state. This, it does deliberately and particularly to cast out the MHF. It was through that medium that CAN influenced and fuelled the unconstitutional and use of both naked and manipulated constitutional powers by the Benue, Taraba and Ekiti States governments to enact the unpopular Anti-Grazing and Anti-Night Grazing Laws (Mohammed \& Aisha, 2018:6, 70, 82, 83, 85 \& 106). This was done to schematically and completely exclude Fulanis from these states since they could not live where their cattle cannot graze around. The other non-Hausa-Fulani, but indigenous Muslims of those states also have their gory stories and experience to tell.

The Nigerian state authorities are fully aware and have acknowledged the problem, while there are intelligence reports and confessional statements from arrested individuals and submissions by citizens, including parliamentarians; the perpetrators continue to execute the genocide with impunity, resistance and shield from arrests; the other ethno-religious groups and bodies equally engage in issuance of press statements, rejoinders, memos which altogether incite their members, promote hate speeches and texts, thereby facilitating the genocide (Daily Trust, July 23, 25 \& 26, 2017 pp.3 \& 17, 11, 4, 42; CAN Press Statement, January 16, 2018; SCIA Press Releases, January 30, 2018, p.1-8 \& April 3, 2019, p.4; NCEF, 2018 pp.1-6).

\section{The Génocidaires and their Targets}

Relying on the UN definition/description of genocide and Alvarez's identification of the perpetrators of genocide, Jones (2011:570) relates that genocidaires are identified by their words and deeds, and they are then challenged consequently. The MHF are the main target of the genocide and it is the direct consequence of killing, exclusions, intimidations, blame, giving bad name and publicity and discriminating against them wherever opportunity avails irrespective of their constitutional/natural rights as humans and citizens of Nigeria. The genocidaires comprise of some elements of Christians (Northern Christian minorities) and their Southern counterparts, the other southern based ethnic groups and their apologists, politicians, public servant (retired and serving). The perpetrators have succeeded in inculcating wrong notions of hatred, despise, resentment, disaffection and prejudices. These are in addition to successfully scheming frame up of the MHF as the scapegoats of Nigeria's failure. Similarly, because of the close affinity between ethnicity and religion as Yinger (1994) emphasizes, the perpetrators have also succeeded in pitching many of the other ethno-religious groups together against the targets. 


\section{The Way Forward}

Having established the occurrence of systematic genocide against the Hausa-Fulani and Muslims of Nigeria, it is imperative for the Nigerian state authorities to rise up to the challenge, apprehend all the culprits and prosecute them accordingly and take other legal measures to stop the act. The possession (legal and illegal), proliferation and use of arms among the Nigerian citizens should be strictly regulated and effectively monitored; the operation of different groups (ethnic, religious, militia among others) and harassment of innocent Nigerian citizens by should all be stopped; religious and social organisations should be enlightened to and preach peace, harmony, brotherhood. The Federal Government of Nigeria (through appropriate avenues) should rise up to the challenge of enactment of discriminatory, controversial and selective legislations which threaten the peaceful co-existence of Nigerians. The rule of law should also be fully enforced on all Nigerians irrespective of whatever status, origin, religion or tribe.

\section{Summary and Conclusion}

No genocides occur overnight, but preceded by some clear indicators and only occur where the world, a state or people close/turn their eyes or neglect such indicators and existing realities. With those, there is a systematic and multi-dimensioned genocide being executed on both covert and overt ground against the MHF in Nigeria. Evidences and measurement standards are available, robust and viral to prove this genocide against the target group. The strategies being used are such that they are simultaneously executed having been preceded by rivalry and conflicts. The role being played by some Nigerian state authorities is typical to bureaucratic perpetration of the genocide and exactly what and how it had earlier occurred in other countries. Some elements/bureaucratic perpetrators of the genocide within the Nigerian security agencies and other public services to cover up the atrocities and thwart all efforts, destroy evidences towards proper investigations, prosecution and punishing the culprits. With those, the targets are continuously being killed, economically crippled and impoverished, physically displaced and psychologically traumatised.

All the perpetrators (their identities, whereabouts, and activities) in the genocide are known to the Nigerian state authorities. There is a complicity between some Nigerian state officials (especially within the armed forces), CAN and the other perpetrators to continue the systematic genocide in addition to instill Islamophobia, manufacture lies, and destruction of the genocide evidences. The perpetrators are fully funded, harboured and public intelligence reports are leaked to them. Their activities are covered up by their fellow culprits and strengthened by state authority's negligence, inaction to prosecute those responsible. All past genocide records show that they started at lowest levels, but neglected by the states and society after which they grew out of control and plunged states and societies into savage, inhumanity and anarchy.

This study is limited to the general act of genocide against the HFM groups of Nigeria. Further studies can investigate and reveal each of the issues raised in this study and conduct an in-depth investigation of the extent of the genocide and the specificity of its systematic kind and nature.

\section{References}

Achebe, C. (2012). There was a country: A personal history of Biafra. London: Penguin Books.

Agnew, R. (2006). Pressured into crime: An overview of general strain theory. Los Angeles: Roxbury Publishing.

Albeely, T. S., Mahmoud, A. T., \& Yahaya, A. I. (2018). Ethnicity, tribalism, and racism and its major doctrines in Nigeria. Dirasa Ifriqiyya 59, 29-46.

Aliyu, A. A. \& Shehu, M. I. (2014). Indigene/settler and ethno-religious conflicts in northern Nigeria: Causes and dimensions. International Journal of Advanced Studies in Ecology, Development and Sustainability, 2(1), 72-80.

Alubo, O. (2006). Ethnic Conflicts and Citizenship Crises in the Central Region. Ibadan: Programme on Ethnic and Federal Studies (PEFS).

Alvarez, A. (2010). Genocidal crimes. Abingdon, Oxon, OX: Routledge.

Arowosegbe, J. O. (2016). Citizenship and resource competition in Nigeria. Anthropological Forum, 26(1), 54-73).

Beachler, D. W. (2011). The genocide debate: Politicians, academics, and victims. New York, NY: Palgrave Macmillan.

Blench, R. (2011). The present in the past: How narratives of the slave-raiding era inform current politics in northern and central Nigeria. In Proceedings of the British Academy, 168, 361-392.

Bourne, R. (2015). Nigeria: A new history of a turbulent century. London: Zed Books.

Campbell, K. (2001), Genocide and the global village. New York, NY: Palgrave

Card, C. \& Marsoobian, A. (Eds.). (2007). Genocide's aftermath: Responsibility and repair. Oxford: Blackwell 
Publishing.

Chirstelow, A. (1985). The 'Yan Tatsine disturbances in Kano-A Search for perspective. The Muslim World, 75(2), 69-84.

Christian Association of Nigeria (CAN). Press statement. January 16, 2018. Abuja, Nigeria.

Chow, T.W., Salleh, L.M. \& Ismail, I. A., (2017). Lessons from Major Leadership Theories in comparison to the Competency Theory for Leadership Practice. Journal of Business and Social Review in Emerging Economies, 3(2) 147-156. DOI: https://doi.org/10.26710/jbsee.v3i2.86

Daily Trust January 8, 2018, pp.1, 8 \& 11.

Daily Trust, July 3, 2017. Vol. 42, No. 91, pp.1 \& 53.

Daily Trust, March 2, 2018. Vol. 44 No. 65, pp.4). Many feared dead in fresh Mambilla attack. Magaji Isa Hunkuyi, Gembu.

Daily Trust, March 3, 2018. Vol.19 No. 92, pp.6. 15 Fulani settlements razed in Mambilla. Witnesses claim 14 killed, police say 4. Magaji Isa Hunkuyi, Jalingo.

David, S. T. (2018). Biafra and the question of genocide: Examining the dimensions of violence inheroes and toads of war. Journal of Literary Studies, 34(2), 27-47.

Douglas, T. (1995), Scapegoats: transferring blame. Routlegde: London.

Dutton, D. G. (2007). Psychology of genocide, massacres, and extreme violence: Why 'normal' people come to commit atrocities. Westport, CT: Praeger Security International.

Elazar, D. J. (1987). Exploring federalism. Tuscaloosa: University of Alabama Press.

Eme, K. U. (2012). Government as fuel for religious crisis in Nigeria. In O. Simon, \& U. N. Isidore (Eds.), Boko

Haram and terrorism: Religious Conflicts and dialogue initiatives in Nigeria (Vol. 2, pp. 191-203). Enugu: Snaap Press

Ezeibe, C. C., \& Ikeanyibe, O. M. (2017). Ethnic politics, hate speech, and access to political power in Nigeria. Africa Today, 63(4), 64-83.

Falola, T. (1999). The history of Nigeria. Westport, CT: Greenwood Press.

Falola, T., \& Heaton, M. M. (2008). A history of Nigeria. London: Cambridge University Press.

Gallagher, A. (2013). Genocide and its threat to contemporary international order. London: Palgrave Macmillan.

Gambari, I, Agwai, M. L., Ibrahim, J., Jega, A., Kwaja, C., Fesse, N. Oyebode, A. M., \& Yau, Y. Z. (2018). Pastoralism-farmers conflict and the search for a peaceful resolution. In Daily Trust, January 9, 2018, 44(27), pp.10-11.

Gellately, R. \& Kiernan, B. (Eds.). (2003). The specter of genocide: Mass murder in historical perspective. Cambridge: Cambridge University Press.

Gilligan, J, (1996), Violence: Reflections on a national epidemic, Vintage Books, New York, NY.

Glover, J. (1999), Humanity: A moral history of the twentieth Century. New Haven CT: Yale University Press.

Halliru, T. (2012). Ethno-religious and political conflicts: A study of north-eastern region of Nigeria (2000-2007).

Unpublished PhD Dissertation. University Utara, Malaysia.

Hinton, A. L. (2005). Why did they kill? Cambodia in the shadow of genocide. Berkeley, CA: University of California Press.

Ikegbu, E. A. (2010). Unity and national development in Nigeria. African Journal of Religion, Culture and Society, 2, 119-126.

International Crisis Group (ICG). (2010, December 20). Northern Nigeria: Background to conflict. Africa

Report $\mathrm{N}^{\circ} 168$. Retrieved from http://www.unhcr.org/refworld/docid/4d104b7c2.html.

Itumo, A. (2017). Indigeneity and citizenship questions in Nigeria. African Journal of Politics and Administrative Studies, 6(1), 1-15.

Johnston, H. A. S. (1967). The Fulani Empire of Sokoto. London: Oxford University Press.

Jones, A. (2011). Genocide: A comprehensive introduction. Oxon, OX: Routlegde. (Second Edition).

Joseph, P., \& Randall, S. (2009). Working through conflict: Strategies for relationships, groups \& organisations.

New York, NY: Pearson Education. (Sixth Edition).

Junaidu, A. (1957). Tarihin Fulani. Zaria: Huda Huda Publishing.

Kalu, N. K. (2008). State power, autarchy, and political conquest in Nigerian federalism. Plymouth, UK: Lexington Books.

Kukah, M. H. (1993). Religion, politics and power in northern Nigeria. Ibadan: Spectrum Books.

Kukah, M. H., \& Falola, T. (1996). Religious militancy and self-assertion: Islam and politics in Nigeria. Aldershot, Hants, England: Avebury.

Last, M. (1967). The Sokoto caliphate. London: Longman Group. 
Last, M. (2010). The book and the nature of knowledge in Muslim Northern Nigeria, 1457-2007. In The TransSaharan Book Trade (pp. 175-212). Brill.

Lattimer, M. (Ed.). (2007). Genocide and human rights. Aldershot Hampshire, England: Ashgate Publishing.

Lemkin, R, (2005), Axis rule in occupied Europe: Laws of occupation, Analysis of government, proposals for redress. $\quad$ New Jersey, NJ: Law Book Exchange.

Lenshie, N. E., \& Akipu, I. S. (2014). Clash of religious civilisations in Nigeria: Understanding dynamics of religious violence. Research on Humanities and Social Sciences, 4(17), 47-60.

LeVan, A. C., \& Ukata, P. (Eds.). (2018). The Oxford Handbook of Nigerian Politics. Oxford: Oxford University Press.

Mann, M. (2005). The dark side of democracy: Explaining ethnic cleansing. New York, NY: Cambridge University Press.

Mayersen, D. (Ed.). (2016). The United Nations and genocide. Palgrave Macmillan, London.

McCormick, J. (2010). Comparative politics in transition. Boston: Wadsworth Cengage Learning.

McGarry, J., \& O'leary, B. (Eds.). (1993). The politics of ethnic conflict regulation. London: Routledge.

Midlarsky, M. I. (2005). The killing trap: Genocide in the twentieth Century. Cambridge: Cambridge University Press.

Milgram, S. (1960), Obedience to authority. New York, NY: Harper Torchbooks.

Mooney, L. A., Knox, D. \& Schacht, C. (2002). Understanding social problems. Belmont: Wadsworth/Thomson Learning.

Moses, A. D. (Ed.). (2008). Empire, colony genocide: Conquest, occupation, and subaltern resistance in world history. New York, NY: Berghahn Books.

National Christian Elders Forum (NCEF). (2018). The imperative of Christian participation $\quad$ in governance. RCCG Mega Political Conference. Lagos June 15.

Nigeria Supreme Council of Islamic Affairs (NSCIA). (2018). Press Releases. July 5. \& April 3, 2019. AbujaNigeria.

Nwabueze, B. O. (1993). Ideas and facts in constitution making. Ibadan: Spectrum Books.

Obasanjo, O. (2004). "Text of broadcast to the nation on the declaration of a state of emergency in Plateau state," Daily Trust Newspaper, Abuja, Wednesday, May 19.

Ochonu, M. (2008). Colonialism within colonialism: the Hausa-Caliphate imaginary and the British colonial administration of the Nigerian Middle Belt. African Studies Quarterly, 10(2-3), 95-127.

Okello, A. L., Majekodunmi, A. O., Malala, A., Welburn, S. C., \& Smith, J. (2014), Identifying motivators for state- pastoralist dialogue: Exploring the relationships between livestock services, self-organisation and conflict in Nigeria's pastoralist Fulani. Pastoralism Springer, 4(12), 1-14.

Okoye, G. O. (2013). Ethno-religious conflict in northern Nigeria: The latency of episodic genocide. A PhD Dissertation: Nova Southeastern University.

Okoye, G. O. (2014). Proclivity to genocide: Northern Nigeria ethno-religious conflict, 1966 to present. Lexington Books.

Osaghae, E. E. (1998). Crippled giant: Nigeria since independence. Bloomington, IN: Indiana University Press.

Osaghae, E. E. (2017). Conflicts without borders: Fulani herdsmen and deadly ethnic riots in Nigeria. The Fabric of Peace in Africa: Looking beyond the State, 49-66.

Othman, M. F. B., Osman, N. B., \& Mohammed, I. S. (2019). Restructuring Nigeria: The dilemma and critical issues. Journal of Business and Social Review in Emerging Economies, 5(1), 79-98. DOI: 10.26710/jbsee.v5i1.567.

Othman, S. (1984). Classes, crisis and coup: The demise of Shagari's regime. African Affairs, 83(333), 441-461.

Paden, J.N., (1986). Values and leadership in Nigeria. Ahmadu Bello Sardauna of Sokoto. Zaria: Huda-Huda Publishing Company.

Putnam, R. D. (2007). E pluribus unum: Diversity and community in the twenty-first century the 2006 Johan Skytte Prize Lecture. Scandinavian political studies, 30(2), 137-174.

Roskin, M. (2007). Countries and concepts: Politics, geography, culture. New Jersey, NJ: Pearson Prentice Hall. (9th Ed.).

Rummel, R. J. (1994), Death by government, New Brunswik, NJ, Transaction.

Saidu, B., Rasheed, Z. H., Zakuan, U. A. B. A. \& Yusoff, K. Z. B. . (2019). Restructuring and The Dilemma of State Police in Nigeria: To be or not To Be? Journal of Business and Social Review in Emerging economies, 5(1), 41-50. DOI:10.26710/jbsee.v5i1.554.

Shaw, M. (2015). What is genocide? Malden, MA: Polity Press.

Shehu, M. I., Othman, M. F. B., \& Osman, N. B. (2017). Ethno-religious and regional rivalry in Nigeria: An old 
and creeping trend. Asian Journal of Multidisciplinary Studies, 5(5). 14-24.

Smith, D, (2007). The most dangerous animal: Human nature and the origins of war. New York, NY: St. Martin's Press.

Staub, E. (2002). The psychology of bystanders, perpetrators, and heroic helpers. In L. Newman and R. Erber (Eds.), Understanding genocide: the social psychology of the Holocaust: New York, NY: Oxford University Press.

Sternberg, R. J. (2003). A duplex theory of hate: Development and application to terrorism, massacres, and genocide. Review of General Psychology, 7(3), 299- 328.

Stevens, A. (2004). The roots of war and terror. London: Continuum.

Suleiman, S. (2012). 'Exhuming passions': Religion and the emergence of the .Middle Belt Struggle in Nigeria. Annual Review of Islam in Africa, 11, 18-24.

Suleiman, S. (2015). The Nigerian history machine and the production of Middle Belt historiography (Doctoral dissertation, University of Cape Town).

Totten, S. \& Parsons, W. S. (Eds.). (2009). Century of genocide: Critical essays and eyewitness accounts. New York, NY: Routledge. (3rd Edition).

Turaki, Y. (1993). The British colonial legacy in northern Nigeria: A social ethical analysis of the colonial and post colonial society and politics in Nigeria. Jos: Quarness Publishers.

United Nations (UN). (2004). Genocide is Threat to Peace requiring Strong, united action - Secretary-General Tells Stockholm International Forum, SG/SM/9126, 26 January (Press Release).

Weitz, E. D. (2003). A century of genocide: Utopias of race and nation. Princeton, NJ: Princeton University Press.

Yahaya, A. (2016). Colonialism in the stateless societies of Africa: A historical overview of administrative policies and enduring consequences in southern Zaria districts, Nigeria. African Social Science Review, 8(1), 49-70.

Yinger, M. (1994). Ethinicity. New York, NY: State University Press.

Young, M. B., \& Isbell, Paul. (2000). In God's time: Building a democratic nation. Quebecor: Hampton 
